DOI $10.21685 / 2500-0578-2021-2-1$

\title{
NATURAL ZONALITY OF THE FOREST BELT OF NORTHERN EURASIA: MYTH OR REALITY? PART 2 (LITERATURE REVIEW)
}

\author{
O. V. Smirnova', A. P. Geraskina ${ }^{2}$, V. N. Korotkov 3 \\ ${ }^{1,2}$ Center for Forest Ecology and Productivity, Russian Academy of Sciences, \\ 84/32 Profsoyuznaya Street, Moscow, 117997, Russia \\ ${ }^{3}$ Yu. A. Israel Institute of Global Climate and Ecology, 20B Glebovskaya st., Moscow, 107258, Russia \\ 1ovsinfo@gmail.com, 2ªngersgma@gmail.com, 3 korotkovv@list.ru
}

Abstract. Solving the problems of sustainable existence of the biota in Northern Eurasia requires a detailed analysis of the interactions between human and nature at the initial stage of the development of this territory. Paleoreconstructions of the structural and functional organization of the biota in the analyzed territory at different stages of its development constitute the necessary basis for solving the problems of preserving and restoring natural laws, which are absolutely necessary for a deep understanding of natural mechanisms, as the main condition for the survival of mankind. The initial stage of interaction between human and nature called "appropriating economy" was marked by the destruction of complementary systems - the basis of the sustainable existence of nature as a whole. The main reason is the almost complete destruction of the giant phytophagous mammoth complex. The next period of interaction between human and nature is "the stage of the productive economy", in which slash-and-burn agriculture became the main method of agricultural development of forest areas in Northern Eurasia. This type of Nature management caused a decrease in the productivity of forest ecosystems, associated with the loss of nutrients after the burning of the stand, with the loss of soil biota and a decrease in soil fertility. Thus, the pre-anthropogenic biota is replaced by modern fragments of anthropogenically transformed areas. Currently, when the still preserved species and their groups cannot be maintained by nature itself, we need to develop and implement large-scale measures to restore the biota and its climate-regulating functions as soon as possible.

Keywords: slash and burn agriculture, climate, paleohistory, complementarity, forest, ecosystem, plowing, soil

Financing. The work was conducted on the topic of the CEPL RAS "Methodological approaches to assessing the structural organization and functioning of forest ecosystems" AAAA-A18-118052590019-7 and with the financial support of the RFBR No. 19-04-00-609 A (analysis of paleohistory and paleoreconstruction of the biota of Northern Eurasia) and RSF No. 21-74-20171 (analysis of the state of soils after plowing).

For citation: Smirnova O.V., Geraskina A.P., Korotkov V.N. Natural zonality of the forest belt of Northern eurasia: myth or reality? Part 2 (literature review). Russian Journal of Ecosystem Ecology. 2021;6(2). Available from: https://doi.org/10.21685/2500-0578-2021-2-1

\section{ПРИРОДНАЯ ЗОНАЛЬНОСТЬ ЛЕСНОГО ПОЯСА СЕВЕРНОЙ ЕВРАЗИИ: МИФ ИЛИ РЕАЛЬНОСТЬ? ЧАСТЬ 2 (ОБЗОР ЛИТЕРАТУРЫ)}

\author{
О. В. Смирнова', А. П. Гераськина ${ }^{2}$, В. Н. Коротков ${ }^{3}$ \\ 1, 2 Центр по проблемам экологии и продуктивности лесов РАН, Россия, 117997, г. Москва, ул. Профсоюзная, 84/32 \\ ${ }^{3}$ Институт глобального климата и экологии имени академика Ю. А. Израэля, Россия, 107258, г. Москва, ул. Глебовская, 20Б \\ 'ovsinfo@gmail.com, 2angersgma@gmail.com, ${ }^{3}$ korotkovv@list.ru
}

Аннотация. Решение проблем устойчивого существования биоты Северной Евразии требует детального анализа взаимодействия человека и природы на начальном этапе освоения этой территории. Палеореконструкции структурно-функциональной организации биоты на анализируемой территории на разных этапах ее развития составляют необходимую основу для решения проблем сохранения и восстановления природных закономерностей, абсолютно необходимых для глубокого понимания законов жизни природы как основного условия выживания человечества. Начальный этап взаимодействия человека и природы, получивший название «этап присваивающего хозяйства», ознаменован разрушением комплементарных систем - основы устойчивого существования природы в целом. Главная причина - практически полное уничтожение гигантов- 
фитофагов мамонтового комплекса. Следующий период взаимодействия человека и природы: «этап производящего хозяйства», на котором основным способом сельскохозяйственного освоения лесных пространств Северной Евразии стало подсечно-огневое земледелие. В результате этого типа природопользования снижается продуктивность лесных экосистем, которая связана с потерями биогенных элементов после выжигания древостоя, с утратой почвенной биоты и снижением почвенного плодородия. Таким образом, происходит замена доантропогенной биоты фрагментами антропогенно преобразованных территорий. Современное состояние природы, практически полностью лишенной возможности самостоятельного выживания еще сохранившихся видов и их групп, требует незамедлительной разработки и проведения масштабных мероприятий по восстановлению Биоты и ее климаторегулирующих функций.

Ключевые слова: подсечно-огневое земледелие, климат, палеоистория, взаимодополняемость, лес, экосистема, вспашка, почва

Финансирование. Работа проводилась по теме ЦЭПЛ РАН «Методические подходы к оценке структурной организации и функционирования лесных экосистем» АААА-А18-118052590019-7 и при финансовой поддержке РФФИ № 19-04-00-609 А. (анализ палеоистории и палеореконструкции биоты Северной Евразии) и РСФ № 2174-20171 (анализ состояния почв после вспашки).

Аля цитирования: Смирнова О. В., Гераськина А. П., Коротков В. Н. Природная зональность лесного пояса Северной Евразии: миф или реальность? Часть 2 (обзор литературы) // Russian Journal of Ecosystem Ecology. 2021. Vol. 6 (2). https://doi.org/10.21685/2500-0578-2021-2-1

The analysis of the paleohistory of Northern Eurasia, conducted in the first part of our review [1], demonstrates the enormous damage caused to the nature of Northern Eurasia by human at the initial stage of the development of this area. To solve the problem of sustainable existence of nature in Northern Eurasia, we need to continue analyzing these interactions.

Only the constant accumulation of a large array of paleodata, documents on the history of nature management and field data on the current state of the living cover of the analyzed areas will make it possible to characterize the enormous losses of biota at the initial stages of its development by the human, as well as to assess the ongoing degradation of nature associated with an increase in anthropogenic impact [2].

"Even in our time, a significant part of ecologists and biogeographers are still convinced that living organisms and their communities can adapt only to the conditions that are independently created in the lithosphere, hydrosphere, and atmosphere. Ignoring the environment-transforming role of organisms, ecologists reduce all the dynamics that gave rise to the diversity of communities to their reflection of climate changes, tectonic movements of the earth's crust, or to the reflection of a one-way connection with soils with different texture and moisture content" [3].

Despite all the concerns about the disastrous state of the Earth's nature, indicated in the appeals of the Club of Rome about the need for urgent assistance to nature, before modern statements about the growing danger of biospheric catastrophes, the destruction of nature continues $[4,5]$. At the same time, we seek to understand the laws of nature as deeply as possible based on the analysis of "com- plementary systems" [6] - complex kinds of different natural kingdoms organized and governed by key species that maintain a stable climate and regulate the intensity of generation flows of creatures living together. An obstacle to awareness of the need for reconstructions of "complementary systems", which constituted the basis of the sustainable life of nature before the appearance of human, is the fact that the "fragments" of nature that have survived in reserves and other protected areas (PAs) are considered by the majority of people, including researchers of the reserves, as undisturbed natural formations $[7,8]$.

Awareness of natural destructions is hindered by:

1. Insufficient biological literacy of people our country due to the lack of full-fledged school and university education, which should include: analysis of the paleohistory of the Russian nature, comparison of its state before the appearance of human with its current state, familiarity with domestic and international methods of preserving and restoring the sustainable functioning of nature as the main condition for survival of humanity on Earth.

2. The heads of reserves and other specially protected natural areas lack the latest knowledge of the basics of paleobiology and ample opportunities for the use of modern methods of scientific research.

The available paleohistorical data for almost any country allows for navigation in the basic laws of nature, minimizing its destruction and extirpation of species through public education, starting from school. Setting the tasks of preserving and restoring nature, it is necessary, as a basis for the development of methods for their solution, to analyze the paleohistory of areas, in which the preanthropogenic natural ecosystems are intended to 
be restored or it is planned to create their analogues $[1,2]$. First of all, this applies to reserves and other specially protected natural areas (SPNA), the documented analysis of the paleohistory of which is the necessary basis for the reconstruction of their prehistoric landscapes.

Currently the solution to this problem becomes possible due to the increasing amount of paleodata on the nature of Northern Eurasia. An analysis of the paleohistory of nature in Northern Eurasia, conducted on the basis of osteological and palynological data, makes it possible to characterize the features of its biota since the beginning of its development by the human (40-10 thousand years ago) [8-12].

Distinctive feature of this period coinciding with the most intensive hunting of human for animals is that at the sites of human remains were found the bones of mammoths, bison, beavers, and animals of modern tundra (reindeer), steppes (saiga, marmots, ground squirrels), and forests (elk, wild boar, beaver, and others), which currently characterize different "natural zones" $[1,2,10]$. Information about the beginning of the development of nature in Northern Eurasia by the human is based on dated paleodata: 1) bone and other remains of animals preserved in refugia and similar habitats; 2) fragments of wood, phytoliths, pollen, seeds, and spores of various plant species.

The joint presence in the same localities of bones and skins of various animals, pollen, and macroremains of different species of broad-leaved and dark coniferous trees, nemoral and boreal grasses, as well as a huge variety of other creatures, demonstrates fundamental differences in the composition, structure, and spatial distribution of groups and complexes of species from their modern distribution $[2,8-12]$.

Paleoreconstructions demonstrate fundamental differences in the composition, structure, and spatial distribution of groups of species of different natural kingdoms that lived before the appearance of human in the territory of Northern Eurasia from the modern "zonal division" of the analyzed territory. The reasons for this division are not yet fully understood by researchers [9-12].

Paleoreconstructions of the structural and functional organization of the biota in the analyzed areas at different stages of its development constitute the necessary basis for solving the problems of preserving and restoring natural laws necessary for a deeper understanding of the laws of nature as the main condition for the survival of mankind [10-12].

In this regard, we consider it important to widely disseminate data on the changes in nature from the date of initial human impact to the present day. We consider these data as the basis for revising our relationship with nature, orienting them towards the search for methods of restoring its structure close to pre-anthropogenic.

The initial stage of interaction between human and nature, described in the first part of our review [1], showed that the period of its development by the human, called the "stage of appropriating economy" $[13,14]$, is marked by the destruction of complementary systems, which are the basis for the sustainable existence of nature as a whole. The main reason is the almost complete destruction of the phytophagous giants of the mammoth complex, which acted as organizers and guardians of nature before the appearance of the human, and also served as the main food resource for the human at the stage of development of Northern Eurasia [1, 2, 12].

"In the late period of the Upper Paleolithic on the Russian Plain and in Siberia, as already indicated, was formed a special historical and cultural community of mammoth hunters, where the mammoth satisfied all the human needs. Of course, they hunted other animals as well, as evidenced by the lists of fauna, but the mammoth, which in all respects ensured their very existence, was the main hunting prey" [15].

The catastrophic consequences of the destruction of the phytophagous giants of the mammoth complex at the early stage of the development of Northern Eurasia are not yet fully understood by both biologists and the Russian population. This determines the small possibility of preserving surviving plant and animal species and representatives of other kingdoms without creating analogues of complementary systems of the pre-anthropogenic period by reintroducing surviving species and imitating the main components of prehistoric landscapes.

Taking into account the significance of the destructive impacts of the appropriating economy on nature, we consider it necessary to characterize their consequences that all people need to know, since our life depends on our ability to preserve and restore nature $[1,9-12]$.

Consequences of the impacts of the appropriating economy include:

1. Weakening of the climate-regulating role of the Biota in Northern Eurasia consisting of the phytophagous giants of the mammoth complex and the accompanying suite of species from different natural kingdoms. The data on the warming effect of farm animals as a significant source of greenhouse gases [16-18] confirmed the concept of the climate-regulating role of the biota of Northern Eurasia. This made it possible to more clearly understand the reasons for the change in climatic conditions as a result of the almost complete de- 
struction of the giant phytophagous mammoth complex.

2. Degradation of the structural and functional organization of complementary systems of species of different natural kingdoms is a consequence of the extinction of many of its participants: animals, plants, and representatives of other kingdoms, favorable conditions for whose life were created by key species - phytophagous giants of the mammoth complex [1,9-12].

3. Depletion of the species composition, a drop in the productivity of grasses, mainly of those with intercalary meristems, the leaves of which grow back after being bitten by herbivores, whose saliva contains enzymes, activating tillering and growth of shoots of cereals [19].

4. Decline in soil fertility as a result of the death of representatives of the soil biota due to the absence of an important trophic resource - the excrement of large animals, as well as the destruction of habitats previously created by phytophagous giants and their retinue $[1,20,21]$.

5. The death of many inhabitants of the soil, necessary to maintain its optimal composition and structure violated by fires, in the process of fire hunting for large animals [12-14, 22, 23]. "A feature of the current stage of research on vegetation cover is the awareness of the need for close attention to the history of the relationship between human and nature over a long stage of conventional Nature management" [12]. "The primitiveness of economic activity in the Neolithic does not make it possible to deny the active influence of the human on nature in this epoch. The human mastered fire, which allowed him to settle not only in the steppe and forest-steppe areas, but also to move far to the north. Thus, the impact of human on nature in this initial period of culture was significant, especially in connection with the use of forest and steppe fires during hunting in dry periods of the year" [15].

6. A significant reduction in the species composition and number of populations of animals, plants, fungi, microorganisms, and other creatures, whose life depended on the phytophagous giants of the mammoth complex, who during their life course created the habitats they needed: glades, trails, fallen trees, mounds, pits, outcrops soils, wetlands, and other formations that change the temperature regime of habitats, maintain the required level of photosynthetically active radiation (PAR), as well as supply them with food resources $[12-14,24]$.

7. Transformation of complexes of complementary systems of forest-meadow landscapes by phytophagous giants of the mammoth complex and the accompanying retinue of vertebrates and invertebrates, as well as representatives of other king- doms, into modern forests - communities that are almost completely devoid of meadow glades and their inhabitants - a variety of light-loving plants, animals, and representatives of other natural kingdoms [9-11].

8. Changes in the habitats of many plant and animal species in Northern Eurasia due to the termination of the environment-transforming and climate-regulating activity of the mammoth complex phytophagous giants, destroyed by the human, and the beginning of the formation of the modern forest belt in climatic conditions determined by anthropogenic methods of management.

The end of the stage of the appropriating economy due to the destruction of the main hunting objects - the phytophagous giants of the mammoth complex $[1,2]$ was followed by the "stage of the producing economy", which included, in addition to hunting and fishing, collecting herbs and fruits, building dwellings, making clothes from animal skins. The two main types of environmental management are:

Type 1 - domestication of animals: cattle, horses, sheep, goats, birds, etc. [13-15]. This type of nature management included: grazing animals on grass glades and in forests preserved after the extinction of mammoths, as well as the organization of seeded meadows; preparation of forest litter for cattle breeding - hay and branch fodder - collection of forest litter for winter stall keeping, preparation of cattle manure for fertilizing sown meadows.

Cattle grazing in forests imitated the impact of large herbivores in pre-anthropogenic forestmeadow landscapes, maintaining their appearance, fertilizing the land and contributing to the conservation of species diversity of trees, grasses and the existence of soil biota. However, during the development of animal husbandry, part of the forestmeadow areas almost completely lost their trees and turned into grass communities: meadows, steppes, wastelands, etc.

Type 2 - slash and burn agriculture [21-23] has been the main method of cultivation of forest areas in Northern Eurasia for thousands of years. At the same time, it caused one of the largest natural disasters, which in some tropical countries continues to the present day. In Russian, this method of Nature management is clearly reflected in the name of the soil formed in the process of slash-and-burn agriculture, "Podzol (literally "under ash") is a soil from under a burnt forest, arable land on sites of fire" [25].

A detailed analysis of slash-and-burn agriculture is given in the book by M.V. Bobrovsky "Forest soils of European Russia: biotic and anthropogenic factors of formation" [24]. This method of Nature management had many options and was the 
main method for many decades in the territory of Northern Eurasia.

"Traces of the former arable land, so often found in the European part of Russia, testify that almost all of the current forests and meadows arose on the site of the former cultivated land..." [21] (Fig. 1).
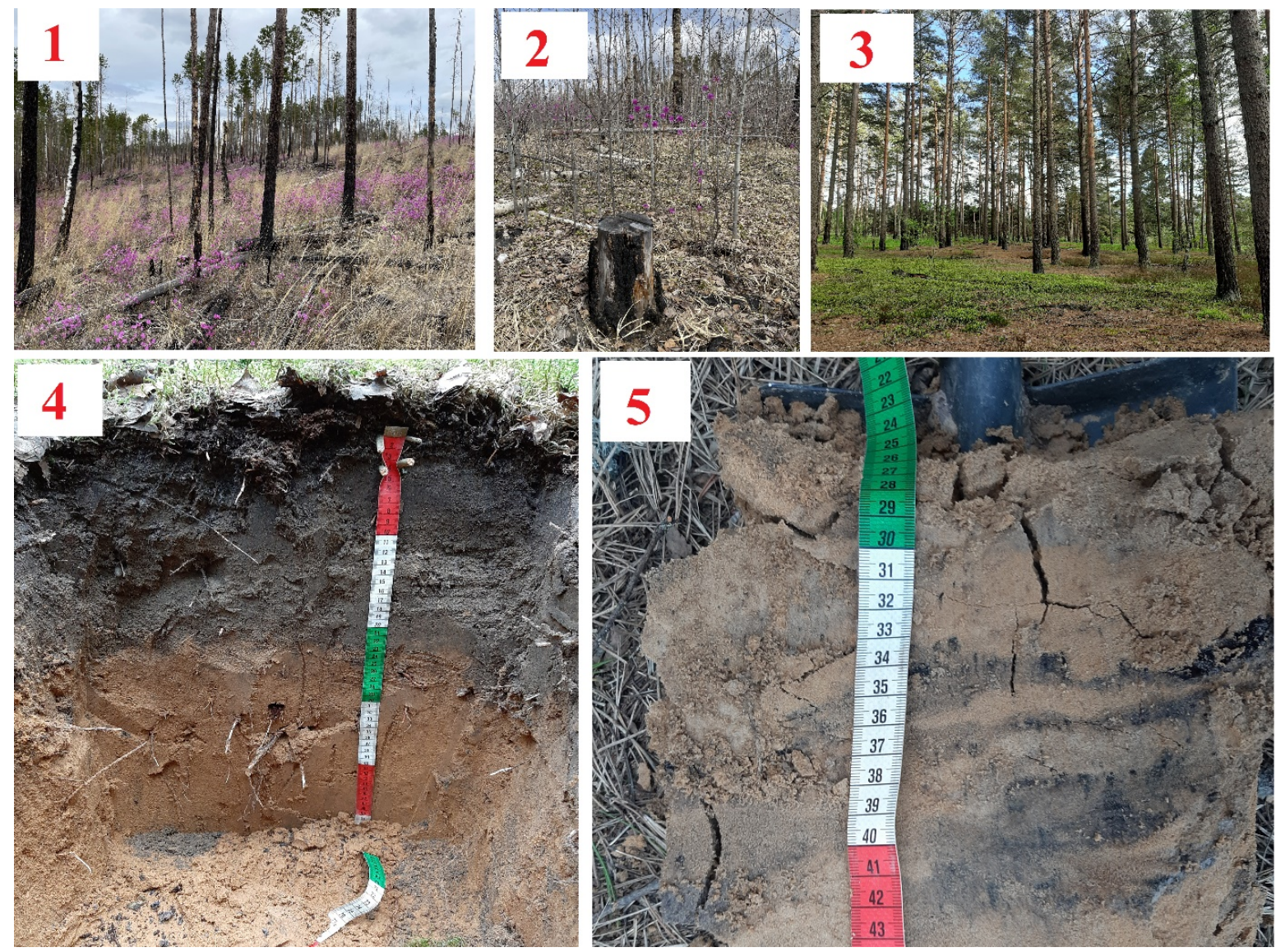

Fig. 1. Traces of fires and plowing in modern forests:

1, 2 - forests in the Irkutsk region after a recent fire (photo by Korotkov V., 2021); 3 - pine forest after a 17-year fire in the Smolensk Lakeland National Park: undergrowth is completely absent (photo by Geraskina A., 2021);

4 - traces of plowing of the first half of the 2oth century in the soil of the spruce forest of the Smolensk

Lakeland National Park (the soil section was made by I. Semenkov, 2021); 5 - traces of old fires in the soil of the modern pine forest of the Smolensk Lakeland National Park (photo by Geraskina A., 2021)

Paleo-studies clearly demonstrate the advantages of the slash-and-burn farming system, thanks to which, the residents of large forest areas preferred this method of farming [21-24] to other methods due to its advantages:

1) high yields in the early years. With such a farming system, the size of the fields could be many times smaller than with other land-use systems;

2) ability to perform many technological operations, primarily the most labour-intensive: ringing or marking tree trunks, as well as felling, outside the growing season, in which farmers were busy with grazing livestock and preparing forage;

3) no need to cultivate the land and manufacture special tools for this, i.e. means of production.

4) a small amount of weeds in the first years of using the forest area due to the "burning" of the soil and the relative remoteness of the cleared areas from the sources of weed seeds.
This method of Nature management was the main among the population of forest areas of the Earth for thousands of years. Thus, even in the late $20^{\text {th }}$ century, at least 240 million people were engaged in slash-and-burn agriculture in tropical forests [24].

In terms of impact on the Earth's Nature as a whole, this type of Nature management can be compared only with the complete extinction of the phytophagous giants of the mammoth belt, which were organizers and keepers of complementary systems, which were the basis of sustainable existence of the biota of Northern Eurasia as a whole [1].

Slash-and-burn agriculture caused a significant decrease in soil fertility in vast areas of Northern Eurasia. An economic cycle in slash-and-burn agriculture lasted 25-80 years.

The most significant consequences of using the slash-and-burn farming system include [21, 24]: 
1. Exposure of the soil surface, depletion of the upper soil horizon, an increase in surface runoff and soil erosion;

2. Transition from subsoil accumulation of organic matter to suprasoil accumulation, which resulted in an increase in the fire hazard to forests [9];

3 . As a result of a short farming cycle was exclusion the possibility of the formation of a gapmosaic, which determine the long and stable existence of generation flows of all inhabitants of forest ecosystems.

4. The absence of natural uprooting of trees-soil complexes (bumps and pits formed as a result of tree felling, as well as large wood residues at different stages of decomposition) - a complex of habitats necessary for many species of soil biota, as well as various grasses, terrestrial vertebrates and invertebrates.

5. Impoverishment of soil fauna and a decrease in soil fertility as a result of exposure to fire. Fires have a catastrophic effect on vegetation (see Fig. 1) and soil biota. First of all, the inhabitants of the litter and soil perish at a depth of $2-3 \mathrm{~cm}$ below the combustion zone. Litter and soil inhabitants die both directly of high temperatures during the fire and after it in the first few days from intoxication with combustion products [26]. Almost $95 \%$ of insects die at the egg stage, and $60 \%$ die at the larval and imago stages. Soil-litter and soil inhabitants are even more vulnerable: ticks, collembolans, shell amoebas, insects and earthworms die en masse in the fire zone. The restoration of the full diversity of soil biota occurs very slowly, especially in groups of animals with low dispersal abilities: earthworms, millipedes, spiders, mollusks [27].

6. A decrease in the productivity of forest ecosystems after the burning of the stand, associated not only with direct losses of biomass accumulated during the period preceding burning, but also with a decrease in the content of mineral nutrients in soils [24].

As follows from the analysis of the literature conducted by M. V. Bobrovsky, all the authors who studied the consequences of slash-and-burn agriculture paid special attention to the adverse results of cutting: soil compaction, decrease in its air capacity and water permeability, significant changes in the chemical composition of the soil, the number of microflora and intensity of microbiological processes [24].

Slash-and-burn agriculture has been practiced to this day, causing significant damage to biota as a whole and changing the climate. Cattle breeding as well as meadow and grass cultivation made it possible to better fertilize the soil than clearing. Therefore, since $14^{\text {th }}$ century, manure has increasingly become an object of purchase and sale; the imports of manure gradually became more intensive, which slowed down the destruction of the soil biota of forests, the burning out of which became less intensive [24].

The subsequent plowing of huge areas for a long time without improving the farming technology led to soil depletion, decreased yield, and abandoning of arable land. The Great Russian Plowing led to massive degradation of the soil cover, which manifested itself in the widest distribution of podzolic soils in the center and north of Eastern Europe, as well as to the degradation of ecotopes and changes in the hydrological regime of the areas [21-24] (see Fig. 1).

Summing up the general results of the initial stage of human development of the Nature in Northern Eurasia, it is necessary to note two most powerful, negative impacts: 1) destruction of phytophagous giants of the mammoth complex; 2) decrease in soil fertility due to the spread of slashand-burn agriculture and mass plowing.

These two impacts changed the climate of Northern Eurasia [12] and, as a consequence, the habitats of plants and animals that have survived from the beginning of its development by the human to the present time.

Cartographic analysis of paleoareals of trees and shrubs, obtained on the basis of spore-pollen analysis data, as well as comparison of paleoareals and modern areas of the same plant species, made it possible to characterize their changes caused by human activity at the stages of appropriating and producing economy $[8,9]$.

The genera of trees in nemoral forests include oak (Quercus), beech (Fagus), Linden (Tilia), maple (Acer), ash (Fraxinus), elm (Ulmus), hornbeam (Carpinus); the genera of trees in boreal forests include spruce (Picea) and fir (Abies) with the ranges of the same genera. Comparison of modern areas of these genera based on the dated spore-pollen information showed that, in contrast to the modern separate arrangement of the ranges of these groups of species, during most of the Holocene, pollen of trees of all the listed genera are found in the same areas within the entire modern forest belt of Northern Eurasia [10].

Since nemoral tree species currently determine the possibility of sustainable existence of a significant number of nemoral grass species, whereas dark coniferous tree species determine the possibility of sustainable existence of a significant number of boreal grasses $[9,10,28]$, it can be assumed that their sustainable coexistence was determined by the environment-transforming and climateregulating activities of complementary systems of species, headed by phytophagous giants of the mammoth complex [1]. 
This conclusion is based on the results of analyses of modern ranges of nemoral and boreal grass species, starting with a work of T. Lipmaa [29] and continued by L. B. Zaugolnova et al. [30, 31]. It was documented that these species grew jointly in most of the modern forest belt of Northern Eurasia, in the found and studied refugia that were not used for slash-and-burn agriculture; they did not suffer fires and other adverse effects on soil and terrestrial flora and fauna.

In addition, on other continents, i.e. in South America, Africa, and Australia, the largest number of finds of preserved paleo-remains of soil fauna (cocoons of earthworms, fragments of coprophagous insects) and traces of their activity (coprolites and earthworm tunnels, tunnels and brood chambers of dung beetles) coincide with a period of flourishing of gregarious mammals and the formation of meadow-marginal biomes. Reconstruction of the morphology and behavior of dung beetles shows a high adaptation to the excrement of mammals inhabiting biomes with a predominance of grasses [20, 32-35]. Open spaces supporting large herbivorous herds producing large amounts of dung are ideal conditions for dung beetles [36].

\section{Recommendations for the restoration of Biota and its climate-regulating functions}

Based on the data of paleoliterature and experience in the conservation and maintenance of biodiversity in modern forest ecosystems, we can distinguish the following focus areas:

1. Restoration and maintenance of key animal species: bison, deer, beavers, etc. [37-40]. Regulating the density of these animals through the management of predator populations, since overgrazing, for example, of reintroduced ungulates, has the opposite effect: soil depletion and loss of biodiversity [41];

2. Restoration and maintenance of key woody plant species, taking into account the need to maintain a mosaic of regeneration gaps in the forest cover: the formation of polydominant stands of different ages, and, if necessary, hollow cuttings with planting or sowing of light-loving tree species in the gaps in the forests of the same age [42-44]. Gaps in the forest canopy can be created by artificial fallouts, when their formation is combined with the creation of windfall-soil complexes that enhance the heterogeneity of the soil cover [2].

3 . Conservation and restoration of in-forest clearings in combination with moderate grazing of livestock or wild animals that significantly increases biodiversity, soil fertility, and creates favorable conditions for light-loving flora at the forest edges; the formation of a clump-glade type of plantations: groups of trees alternate with glades and openings [43, 44].

4. Preservation of dead wood, fallen trees, and stumps necessary for the life of fungi, bacteria, various groups of invertebrates (especially xylobiont insects), birds and mammals [45-47].

5. Measures for the restoration of soil biota, which M. S. Gilyarov [48] referred to as "zoological soil reclamation" and assumed great prospects from the introduction of this method. He believed, "The introduction of species of invertebrate soilformers absent in a given territory is technically the simplest and most effective method of zoological soil reclamation." There is a successful experience in the reintroduction of earthworms [49-52] and the introduction of dung beetles [53, 54]. Frequent inadvertent reintroduction of earthworms along with planting material turns out to be useful for the restoration of soil fertility [55].

6. A set of measures conducted when the soil is severely degraded, i.e. transplantation of blocks of the upper soil layers from nearby regions, often contribute to a faster and more stable settlement of the restored areas by soil fauna in comparison with measures for the reintroduction of soil fauna without soil [56].

\section{Conclusion}

Based on the analysis of the literature, we can identify the main stages of degradation of the living cover of Northern Eurasia:

1. Complete extinction of natural key species of phytophagous giants of the mammoth complex, which are the most accessible objects of collective hunting.

2. Destruction of herbal ecosystems by the codominance of cereals, the transformation of forestmeadow landscapes into forest landscapes.

3. Formation of modern zoning - division of a single cover into "natural" zones: tundra, coniferous, mixed, and deciduous forests, steppes, and semi-deserts in accordance with the methods of Nature management - herd reindeer husbandry in the north; slash-and-burn agriculture and grazing in most of the modern forest belt; agriculture and cattle breeding in the south of the modern belt of steppes and semi-deserts.

4. Replacement of pre-anthropogenic biota with modern fragments of anthropogenically transformed areas and human economic activity.

Thus, the current state of Nature, almost completely devoid of the possibility of independent survival of the still preserved species and their groups, requires fundamental changes in the relationship between human and nature and immediate actions to restore it. 


\section{Список литературы}

1. Smirnova O. V., Geraskina A. P., Korotkov V. N. Natural zonality of the forest belt of Northern eurasia: myth or reality? Part 1 (literature review) // Russian Journal of Ecosystem Ecology. 2020. Vol. 5 (1). doi: 10.21685/25000578-2020-1-2

2. Восточноевропейские леса: история в голоцене и современность / отв. ред. О. В. Смирнова. М. : Наука, 2004. Кн. 1. 479 с.

3. Смагин В. Н. Основные закономерности развития и смены лесных биогеоценозов // Динамика лесных биогеоценозов Сибири. Новосибирск, 1980. С. 62.

4. Пестель Э. За пределами роста. М. : Прогресс, 1988. 272 с.

5. Verheyen K., Honnay O., Bossuyt B., Hermy M. What history can teach us about present and future forest biodiversity // Forest biodiversity: Lessons from history for conservation. UK and Cambridge Oxfordshire : CABI Publishing, 2004. P. 1-10.

6. Smirnova O. V., Geraskina A. P., Aleynikov A. A. The concept "complementarity" as the basis for model and nature reconstruction of potential biota in the current climate // Russian Journal of Ecosystem Ecology. 2018. Vol. 3 (3). doi: 10.21685/2500-0578-2018-3-1

7. Смирнова О. В., Заугольнова Л. Б., Ханина Л. Г. [и др.]. Оценка и сохранение биоразнообразия лесного покрова в заповедниках Европейской России. М. : Научный мир, 2000. 196 с.

8. Smirnova O. V., Geraskina A. P. Current Northern Eurasia forest condition: methods of analysis and restoration of natural biota in protected areas. Literature review and recommendations for required research in protected areas // Russian Journal of Ecosystem Ecology. 2019. Vol. 4 (1). doi: 10.21685/2500-0578-2019-1-1

9. Смирнова О. В., Турубанова С. А., Бобровский М. В. [и др.]. Реконструкция истории лесного пояса Восточной Европы и проблема поддержания биологического разнообразия // Успехи современной биологии. 2001. Т. 121, № 2. С. 144-159.

10. Турубанова С. А. Экологический сценарий истории формирования живого покрова Европейской России и сопредельных территорий на основе реконструкции ареалов ключевых видов животных и растений : дис. ... канд. биол. наук. М., 2002. 199 с.

11. Харитоненков М. А. Роль антропогенного фактора в формировании растительного покрова юга ЗападноСибирской равнины в эпоху традиционного природопользования (с позднего палеолита до конца XIX в.) : дис. ... канд. биол. наук. М., 2012. 308 с.

12. Харитоненков М. А. Экологический сценарий формирования современной лесостепи (на примере ЗападноСибирской равнины) // Ученые записки Казанского университета. Сер. Естественные науки. 2011. Т. 153, № 3. С. 184-196.

13. Глумов Г. А. К вопросу о влиянии хозяйственной деятельности на растительный покров Западной Сибири в период голоцена // Охрана окружающей среды. Пермь, 1959. С. 37-47.

14. Жеребцова Е. А. Специфика присваивающего хозяйства в Пермском Предуралье в VII-XV веках // Вестник Пермского университета. 2015. Вып. 4 (31). С. 7-18.

15. Аникович М. В., Анисюткин Н. К. Человек и мамонт в палеолите Восточной Европы // Мамонт и его окружение: 200 лет изучения. 2001. С. 315-327.

16. O'Mara F. P. The significance of livestock as a contributor to global greenhouse gas emissions today and in the near future // Animal Feed Science and Technology. 2011. Vol. 166. P. 7-15.

17. Saggar S., Bolan N. S., Bhandral R. [et. al.]. Review of emissions of methane, ammonia, and nitrous oxide from animal excreta deposition and farm effluent application in grazed pastures // New Zealand Journal of Agricultural Research. 2004. Vol. 47 (4). P. 513-544.

18. Virkajärvi P., Maljanen M., Saarijärvi K. [et. al.]. $\mathrm{N}_{2} \mathrm{O}$ emissions from boreal grass and grass-clover pasture soils // Agriculture, Ecosystems \& Environment. 2010. Vol. 137. P. 59-67.

19. Алексеева Л. И. Териофауна верхнего плейстоцена Восточной Европы (крупные млекопитающие). М. : Наука, 1989. 109 c.

20. Genise J. F. Soil Neighbors I: Traces of Other Organisms in Paleosols. Crustaceans and Earthworms // Ichnoentomology. Topics in Geobiology. 2017. Vol. 37. doi: 10.1007/978-3-319-28210-7_15

21. Пономаренко Е. В., Пономаренко С. В., Офман Г. Ю., Хавкин В. П. Почва как она есть // Природа. 1993. № 3. C. 16-26.

22. Петров В. П. Подсечное земледелие. М. : Рипол Классик, 2013. 228 с.

23. Кульпин Э. С., Пантин В. И. Генезис кризисов природы и общества в России. М. : Московский лицей, 1993. $102 \mathrm{c}$.

24. Бобровский М. В. Лесные почвы Европейской России: Биотические и антропогенные факторы формирования. М. : КМК, 2010. 359 с.

25. Даль В. И. Толковый словарь живого великорусского языка. М., 1882. Т. 3. 555 с.

26. Wikars L. O., Schimmel J. Immediate effects of fire-severity on soil invertebrates in cut and uncut pine forests // Forest Ecology and Management. 2001. Vol. 141 (3). Р. 189-200.

27. Гонгальский К. Б., Зайцев А. С., Коробушкин Д. И. [и др.]. Роль детритных пищевых сетей в регуляции экологических функций почв после лесных пожаров // Проблемы почвенной зоологии. 2018. С. 62. 
28. Проказина Т. С. Флористическое и экологическое разнообразие темнохвойных лесов западного макросклона Урала // Актуальные проблемы геоботаники : III Всероссийская школа-конференция. Петрозаводск, 2007. Ч. 2. C. 141-145.

29. Lippmaa T. Areal und Alterbestimmung einer Union (Galeobdolon-Asarum-Asperula Union) sowie das Problem der Characterarten und Konstanten. TATU, 1938. 152 s.

30. Заугольнова Л. Б., Смирнова О. В., Браславская Т. Ю. [и др.]. Высокотравные таежные леса восточной части Европейской России // Растительность России. 2009. № 15. С. 3-26.

31. Смирнова О. В., Луговая Д. Л., Проказина Т. С. Модельная реконструкция восстановленного лесного покрова таежных лесов // Успехи современной биологии. 2013. Т. 133, № 2. С. 164-177.

32. Halffter G., Matthews E. The natural history of dung-beetles of the subfamily Scarabaeinae // Folia entomológica mexicana. 1966. № 12-14. P. 1-312.

33. Halffter G., Edmonds W. D. The nesting behaviour of dung beetles. An ecological and evolutive approach // Publs. Instituto de Ecología. Mexico, 1982. Vol. 10. P. 1-176.

34. Hanski I., Cambefort Y. Dung Beetle Ecology. Princeton : Princeton University Press, 2014. doi: $10.1515 / 9781400862092$

35. Scholtz C. H., Chown S. L. The evolution of habitat use and diet in the Scarabaeoidea: a phylogenetic approach // Biology, phylogeny and classifi cation of Coleoptera / ed. by J. Pakaluk, A. Slipinski. Warsaw, 1995. P. 355-374.

36. Scholtz C. H., Davis A. L. V., Kryger U. Evolutionary biology and conservation of dung beetles. Sofia ; Moscow : Pensoft, 2009. 569 p.

37. Nummi P., Kattainen S., Ulander P., Hahtola A. Bats benefit from beavers: a facilitative link between aquatic and terrestrial food webs // Biodiversity and Conservation. 2011. Vol. 20 (4). P. 851-859.

38. Zimov S. A., Zimov N. S., Tikhonov A. N., Chapin III F. S. Mammoth steppe: a high-productivity phenomenon // Quaternary Science Reviews. 2012. Vol. 57. P. 26-45.

39. Van Meerbeek K., Muys B., Schowanek S. D., Svenning J. C. Reconciling Conflicting Paradigms of Biodiversity Conservation: Human Intervention and Rewilding // BioScience. 2019. Vol. 69 (12). P. 997-1007.

40. Van Klink R., van Laar-Wiersma J., Vorst O., Smit C. Rewilding with large herbivores: Positive direct and delayed effects of carrion on plant and arthropod communities // PloS one. 2020. Vol. 15 (1). P. e0226946.

41. Hansen B. B., Henriksen S., Aanes R., Sæther B. E. Ungulate impact on vegetation in a two-level trophic system // Polar Biology. 2007. Vol. 30 (5). P. 549-558.

42. Методические рекомендации по воспроизводству разновозрастных широколиственных лесов европейской части СССР (на основе популяционного анализа) / под ред. О. В. Смирновой, Р. В. Попадюка, А. А. Чистяковой [и др.]. М. : ВАСХНИЛ, 1989. 19 с.

43. Коротков В. Н. Восстановление природных разновозрастных лесов // Современные концепции экологии биосистем и их роль в решении проблем сохранения природы и природопользования. 2016. С. 373-376.

44. Коротков В. Н. Основные концепции и методы восстановления природных лесов Восточной Европы // Russian Journal of Ecosystem Ecology. 2017. Vol. 2 (1). doi: 10.21685/2500-0578-2017-1-1

45. Storch D., Bohdalkova E., Okie J. The more-individuals hypothesis revisited: the role of community abundance in species richness regulation and the productivity-diversity relationship // Ecology Letters. 2018. Vol. 21 (6). P. 920-937.

46. Augustynczik A. L. D., Gutsch M., Basile M. [et. al.]. Socially optimal forest management and biodiversity conservation in temperate forests under climate change // Ecological Economics. 2020. Vol. 169. Article: 106504.

47. Gustafsson L., Bauhus J., Asbeck T. [et. al.]. Retention as an integrated biodiversity conservation approach for continuous-cover forestry in Europe // Ambio. 2020. Vol. 49 (1). P. 85-97.

48. Гиляров М. С. Зоологическая мелиорация почв // Природа. 1976. № 10. С. 18-20.

49. Dunger W., Voigtländer K., Zimdars B. Die Entwiclung der Regenwurmfauna (Lumbricidae) auf den Berzdorfen Halden - repräsentativ für europäische Bergbaugebiete Berichte der Naturforschenden Gesellschaft der Oberlausitz // Berichte der Naturforschenden Gesellschaft der Oberlausitz. 2004. Vol. 11. P. 99-110.

50. Lee K. E. Earthworms and Sustainable Land Use // Earthworm Ecology and Biogeography in North America / ed. by P. Hendrix. Lewis Publishers Boca Raton, 1995. P. 215-234.

51. Butt K. R. Earthworms in soil restoration: lessons learned from United Kingdom case studies of land reclamation // Restoration Ecology. 2008. Vol. 16 (4). P. 637-641.

52. Snyder B. A., Hendrix P. F. Current and potential roles of soil macroinvertebrates (earthworms, millipedes, and isopods) in ecological restoration // Restoration Ecology. 2008. Vol. 16 (4). P. 629-636.

53. Barley K. P. The abundance of earthworms in agricultural land and their possible significance in agriculture // Advances in Agronomy. 1961. Vol. 13. P. 249-268.

54. Bornemissza G. F. Australian dung beetle project 1965-75 // Australian Meat Research Committee. 1976. Vol. 30. P. 1-30.

55. Всеволодова-Перель Т. С., Сиземская М. Л., Колесников А. В. Изменение видового состава и трофической структуры почвенного населения при создании искусственных лесных насаждений в полупустыне Прикаспия // Поволжский экологический журнал. 2010. № 2. С. 142-150.

56. Moradi J., Vicentini F., Šimáčková H. [et. al.]. An investigation into the long-term effect of soil transplant in bare spoil heaps on survival and migration of soil meso and macrofauna // Ecological Engineering. 2018. Vol. 110. P. 158-164. 


\section{References}

1. Smirnova O.V., Geraskina A.P., Korotkov V.N. Natural zonality of the forest belt of Northern eurasia: myth or reality? Part 1 (literature review). Russian Journal of Ecosystem Ecology. 2020;5(1). doi: 10.21685/2500-05782020-1-2

2. Smirnova O.V. (ed.). Vostochnoevropeyskie lesa: istoriya v golotsene $i$ sovremennost' $=$ East European forests: history in the Holocene and modern times. Moscow: Nauka, 2004;1:479. (In Russ.).

3. Smagin V.N. The main patterns of development and change of forest biogeocenoses. Dinamika lesnykh biogeotsenozov Sibiri = Dynamics of forest biogeocenoses in Siberia. Novosibirsk, 1980:62. (In Russ.).

4. Pestel' E. Za predelami rosta = Beyond growth. Moscow: Progress, 1988:272. (In Russ.).

5. Verheyen K., Honnay O., Bossuyt B., Hermy M. What history can teach us about present and future forest biodiversity. Forest biodiversity: Lessons from history for conservation. UK and Cambridge Oxfordshire: CABI Publishing, 2004:1-10.

6. Smirnova O.V., Geraskina A.P., Aleynikov A.A. The concept "complementarity" as the basis for model and nature reconstruction of potential biota in the current climate. Russian Journal of Ecosystem Ecology. 2018;3(3). doi: 10.21685/2500-0578-2018-3-1

7. Smirnova O.V., Zaugol'nova L.B., Khanina L.G. [et al.]. Otsenka i sokhranenie bioraznoobraziya lesnogo pokrova $v$ zapovednikakh Evropeyskoy Rossii = Assessment and conservation of forest biodiversity in the reserves of European Russia. Moscow: Nauchnyy mir, 2000:196. (In Russ.).

8. Smirnova O.V., Geraskina A.P. Current Northern Eurasia forest condition: methods of analysis and restoration of natural biota in protected areas. Literature review and recommendations for required research in protected areas. Russian Journal of Ecosystem Ecology. 2019;4(1). doi: 10.21685/2500-0578-2019-1-1

9. Smirnova O.V., Turubanova S.A., Bobrovskiy M.V. [et al.]. Reconstruction of the history of the forest belt of Eastern Europe and the problem of maintaining biological diversity. Uspekhi sovremennoy biologii = Achievements of modern biology . 2001;121(2):144-159. (In Russ.).

10. Turubanova S.A. Ekologicheskiy stsenariy istorii formirovaniya zhivogo pokrova Evropeyskoy Rossii $i$ sopredel'nykh territoriy na osnove rekonstruktsii arealov klyuchevykh vidov zhivotnykh i rasteniy: dis. kand. biol. $n a u k=$ Ecological scenario of the history of the living cover formation in European Russian and adjacent territories based on the reconstruction of the ranges of key species of animals and plants: thesis of cand. of biol. sciences. Moscow, 2002:199. (In Russ.).

11. Kharitonenkov M.A. Rol' antropogennogo faktora v formirovanii rastitel'nogo pokrova yuga Zapadno-Sibirskoy ravniny $v$ epokhu traditsionnogo prirodopol'zovaniya (s pozdnego paleolita do kontsa XIX v.): dis. kand. biol. $n a u k=$ The role of the anthropogenic factor in the formation of the vegetation cover in the south of the West Siberian Plain in the era of traditional nature management (from the late paleolith until the late XIX century): thesis of cand. of biol. sciences. Moscow, 2012:308. (In Russ.).

12. Kharitonenkov M.A. Ecological scenario of the formation of the modern forest-steppe (on the example of the West Siberian Plain). Uchenye zapiski Kazanskogo universiteta. Ser. Estestvennye nauki = Proceedings of the Kazan University. Natural sciences series. 2011;153(3):184-196. (In Russ.).

13. Glumov G.A. To the question of the influence of economic activity on the vegetation cover of Western Siberia during the Holocene. Okhrana okruzhayushchey sredy = Protection of the environment. Perm, 1959:37-47. (In Russ.).

14. Zherebtsova E.A. The specifics of the appropriating economy in the Perm Cis-Ural region in the VII-XV centuries. Vestnik Permskogo universiteta = Proceedings of the Perm University. 2015;4(31):7-18. (In Russ.).

15. Anikovich M.V., Anisyutkin N.K. Man and Mammoth in the Paleolith of Eastern Europe Mamont $i$ ego okruzhenie: 200 let izucheniya = Mammoth and its surroundings: 200 years of studying. 2001:315-327. (In Russ.).

16. O'Mara F.P. The significance of livestock as a contributor to global greenhouse gas emissions today and in the near future. Animal Feed Science and Technology. 2011;166:7-15.

17. Saggar S., Bolan N.S., Bhandral R. [et. al.]. Review of emissions of methane, ammonia, and nitrous oxide from animal excreta deposition and farm effluent application in grazed pastures. New Zealand Journal of Agricultural Research. 2004;47(4):513-544.

18. Virkajärvi P., Maljanen M., Saarijärvi K. [et. al.]. N2O emissions from boreal grass and grass-clover pasture soils. Agriculture, Ecosystems \& Environment. 2010;137:59-67.

19. Alekseeva L.I. Teriofauna verkhnego pleystotsena Vostochnoy Evropy (krupnye mlekopitayushchie) $=$ Theriofauna of the Upper Pleistocene of Eastern Europe (large mammals). Moscow: Nauka, 1989:109. (In Russ.).

20. Genise J.F. Soil Neighbors I: Traces of Other Organisms in Paleosols. Crustaceans and Earthworms. Ichnoentomology. Topics in Geobiology. 2017;37. doi: 10.1007/978-3-319-28210-7_15

21. Ponomarenko E.V., Ponomarenko S.V., Ofman G.Yu., Khavkin V.P. Soil as it is. Priroda = Nature. 1993;3:1626. (In Russ.).

22. Petrov V.P. Podsechnoe zemledelie = Slash farming. Moscow: Ripol Klassik, 2013:228. (In Russ.).

23. Kul'pin E.S., Pantin V.I. Genezis krizisov prirody $i$ obshchestva $v$ Rossii $=$ The genesis of the crises of nature and society in Russia. Moscow: Moskovskiy litsey, 1993:102. (In Russ.).

24. Bobrovskiy M.V. Lesnye pochvy Evropeyskoy Rossii: Bioticheskie $i$ antropogennye faktory formirovaniya = Forest soils of European Russia: Biotic and anthropogenic factors of formation. Moscow: KMK, 2010:359. (In Russ.). 
25. Dal' V.I. Tolkovyy slovar' zhivogo velikorusskogo yazyka = Explanatory Dictionary of the Living Great Russian Language. Moscow, 1882;3:555. (In Russ.).

26. Wikars L.O., Schimmel J. Immediate effects of fire-severity on soil invertebrates in cut and uncut pine forests. Forest Ecology and Management. 2001;141(3):189-200.

27. Gongal'skiy K.B., Zaytsev A.S., Korobushkin D.I. [et al.]. The role of detrital food webs in the regulation of ecological functions of soils after forest fires. Problemy pochvennoy zoologii = Issues of soil zoology. 2018:62. (In Russ.).

28. Prokazina T.S. Floristic and ecological diversity of dark coniferous forests of the western macroslope of the Urals. Aktual'nye problemy geobotaniki: III Vserossiyskaya shkola-konferentsiya = Topical Problems of Geobotany: III All-Russian School-Conference. Petrozavodsk, 2007;2:141-145. (In Russ.).

29. Lippmaa T. Areal und Alterbestimmung einer Union (Galeobdolon-Asarum-Asperula Union) sowie das Problem der Characterarten und Konstanten. TATU, 1938:152.

30. Zaugol'nova L.B., Smirnova O.V., Braslavskaya T.Yu. [et al.]. Tall-grass taiga forests of the eastern part of European Russia. Rastitel'nost' Rossii = Vegetation of Russia. 2009;15:3-26. (In Russ.).

31. Smirnova O.V., Lugovaya D.L., Prokazina T.S. Model reconstruction of the restored forest cover of taiga forests. Uspekhi sovremennoy biologii = Achievements of modern biology . 2013;133(2):164-177. (In Russ.).

32. Halffter G., Matthews E. The natural history of dung-beetles of the subfamily Scarabaeinae. Folia entomológica mexicana. 1966;12-14:1-312.

33. Halffter G., Edmonds W.D. The nesting behaviour of dung beetles. An ecological and evolutive approach. Publs. Instituto de Ecología. Mexico, 1982;10:1-176.

34. Hanski I., Cambefort Y. Dung Beetle Ecology. Princeton: Princeton University Press, $2014 . \quad$ doi: $10.1515 / 9781400862092$

35. Scholtz C.H., Chown S.L. The evolution of habitat use and diet in the Scarabaeoidea: a phylogenetic approach. Biology, phylogeny and classifi cation of Coleoptera. Warsaw, 1995:355-374.

36. Scholtz C.H., Davis A.L.V., Kryger U. Evolutionary biology and conservation of dung beetles. Sofia; Moscow: Pensoft, 2009:569.

37. Nummi P., Kattainen S., Ulander P., Hahtola A. Bats benefit from beavers: a facilitative link between aquatic and terrestrial food webs. Biodiversity and Conservation. 2011;20(4):851-859.

38. Zimov S.A., Zimov N.S., Tikhonov A.N., Chapin III F.S. Mammoth steppe: a high-productivity phenomenon. Quaternary Science Reviews. 2012;57:26-45.

39. Van Meerbeek K., Muys B., Schowanek S.D., Svenning J.C. Reconciling Conflicting Paradigms of Biodiversity Conservation: Human Intervention and Rewilding. BioScience. 2019;69(12):997-1007.

40. Van Klink R., van Laar-Wiersma J., Vorst O., Smit C. Rewilding with large herbivores: Positive direct and delayed effects of carrion on plant and arthropod communities. PloS one. 2020;15(1):e0226946.

41. Hansen B.B., Henriksen S., Aanes R., Sæther B. E. Ungulate impact on vegetation in a two-level trophic system. Polar Biology. 2007;30(5):549-558.

42. Smirnova O.V., Popadyuk R.V., Chistyakova A.A. (ed.) [et al.]. Metodicheskie rekomendatsii po vosproizvodstvu raznovozrastnykh shirokolistvennykh lesov evropeyskoy chasti SSSR (na osnove populyatsionnogo analiza) = Methodological recommendations for reproducing broad-leaved forests of different ages in the European part of the USSR (based on population analysis) . Moscow: VASKhNIL, 1989:19. (In Russ.).

43. Korotkov V.N. Restoration of natural forests of different ages. Sovremennye kontseptsii ekologii biosistem i ikh rol'v reshenii problem sokhraneniya prirody i prirodopol'zovaniya = Modern concepts of ecology of biosystems and their role in solving problems of nature conservation and nature management. 2016:373-376. (In Russ.).

44. Korotkov V.N. Basic concepts and methods of restoration of natural forests in Eastern Europe. Russian Journal of Ecosystem Ecology. 2017;2(1). (In Russ.). doi: 10.21685/2500-0578-2017-1-1

45. Storch D., Bohdalkova E., Okie J. The more-individuals hypothesis revisited: the role of community abundance in species richness regulation and the productivity-diversity relationship. Ecology Letters. 2018;21(6):920-937.

46. Augustynczik A.L.D., Gutsch M., Basile M. [et. al.]. Socially optimal forest management and biodiversity conservation in temperate forests under climate change. Ecological Economics. 2020;169:106504.

47. Gustafsson L., Bauhus J., Asbeck T. [et. al.]. Retention as an integrated biodiversity conservation approach for continuous-cover forestry in Europe. Ambio. 2020;49(1):85-97.

48. Gilyarov M.S. Zoological soil reclamation. Priroda = Nature. 1976;10:18-20. (In Russ.).

49. Dunger W., Voigtländer K., Zimdars B. Die Entwiclung der Regenwurmfauna (Lumbricidae) auf den Berzdorfen Halden - repräsentativ für europäische Bergbaugebiete Berichte der Naturforschenden Gesellschaft der Oberlausitz. Berichte der Naturforschenden Gesellschaft der Oberlausitz. 2004;11:99-110.

50. Lee K.E. Earthworms and Sustainable Land Use. Earthworm Ecology and Biogeography in North America. Lewis Publishers Boca Raton, 1995:215-234.

51. Butt K.R. Earthworms in soil restoration: lessons learned from United Kingdom case studies of land reclamation. Restoration Ecology. 2008;16(4):637-641.

52. Snyder B.A., Hendrix P.F. Current and potential roles of soil macroinvertebrates (earthworms, millipedes, and isopods) in ecological restoration. Restoration Ecology. 2008;16(4):629-636.

53. Barley K.P. The abundance of earthworms in agricultural land and their possible significance in agriculture. Advances in Agronomy. 1961;13:249-268. 
54. Bornemissza G.F. Australian dung beetle project 1965-75. Australian Meat Research Committee. 1976;30:1-30.

55. Vsevolodova-Perel' T.S., Sizemskaya M.L., Kolesnikov A.V. Changes in the species composition and trophic structure of the soil population during the creation of artificial forest plantations in the semi-desert of the Caspian region. Povolzhckiy ekologicheskiy zhurnal = TheVolga region ecological journal. 2010;2:142-150. (In Russ.).

56. Moradi J., Vicentini F., Šimáčková H. [et. al.]. An investigation into the long-term effect of soil transplant in bare spoil heaps on survival and migration of soil meso and macrofauna. Ecological Engineering. 2018;110:158-164. 